Proc. Estonian Acad. Sci. Biol. Ecol., 2005, 54, 4, 292-301

\title{
On the distribution and taxonomic limits of Lumbricillus pagenstecheri (Oligochaeta, Enchytraeidae)
}

\begin{abstract}
Tarmo Timm
Centre for Limnology, Institute of Agricultural and Environmental Sciences, Estonian Agricultural University, 61101 Rannu, Tartumaa, Estonia; <ttimm@zbi.ee>

Received 12 October 2004, in revised form 20 May 2005

Abstract. Lumbricillus pagenstecheri (Ratzel, 1869) is the most widely distributed and euryhaline representative of a large, mostly littoral, group of Lumbricillus spp. with distinct glandular cover on the ectal spermathecal duct, and a rosette of glands at its ectal end. It is the only species in this group that has been recorded from the shores of both the Atlantic and Pacific oceans and from soil. A freshwater, maybe landlocked, population lives in Lake Kuril'skoe (Far East). It is not identical with L. kamtschatkanus Michaelsen (1929), which was previously reported from the same lake. Lumbricillus pagenstecheri as currently recognized is morphologically different from the rich assemblage of related species from marine littoral of the North Pacific while no clear differences are found between its own marine and freshwater populations.
\end{abstract}

Key words: Lumbricillus, taxonomy, distribution, freshwater fauna.

\section{INTRODUCTION}

Lumbricillus pagenstecheri was first described as Enchytraeus Pagenstecheri by Ratzel (1869) from decaying freshwater vegetation in Germany, and later on emended by Vejdovský (1879) and Ude (1892), similarly on inland material. Vejdovský (1879) recorded it from "ammoniakhaltigen Localitäten", apparently meaning polluted freshwater, and Ude (1892) from wet soil enriched with horse manure. The 20th century records are exclusively for marine littoral habitats, mostly from decaying seaweed.

The worms described as Pachydrilus Pagenstecheri by Vejdovský (1879) and Ude (1892), as well as Lumbricillus pagenstecheri by Nielsen \& Christensen (1959) and subsequent authors, had an ectal spermathecal duct covered with gland cells, and a rosette of larger glands surrounding its ectal end (see, e.g., Erséus 1976). These glands were not mentioned in the short original description by Ratzel 
(1869) and the chaetae were almost straight and more numerous (6-10) than reported in later records. Thus the identity of the recent records with the species that was originally described is open to some doubt. There exists no type material (Reynolds \& Cook 1976).

Later on, a number of Lumbricillus species with spermathecae of the similar type but different in various other characteristics, have been described, mostly from marine littoral. Herewith I give a survey of them, trying to compare them with the L. pagenstecheri as presented in the classical monograph by Nielsen \& Christensen (1959), and discussing their possible relations with one another.

\section{MATERIAL}

My own material originates from Lake Kuril'skoe on the Kamchatka Peninsula, Russian Far East (Fig. 1). About 8860 specimens of L. pagenstecheri were collected there in 1994-1998 with routine zoobenthos samples (Timm \& Vvedenskaja submitted). Thirteen of them were studied in serial sections, the rest as whole

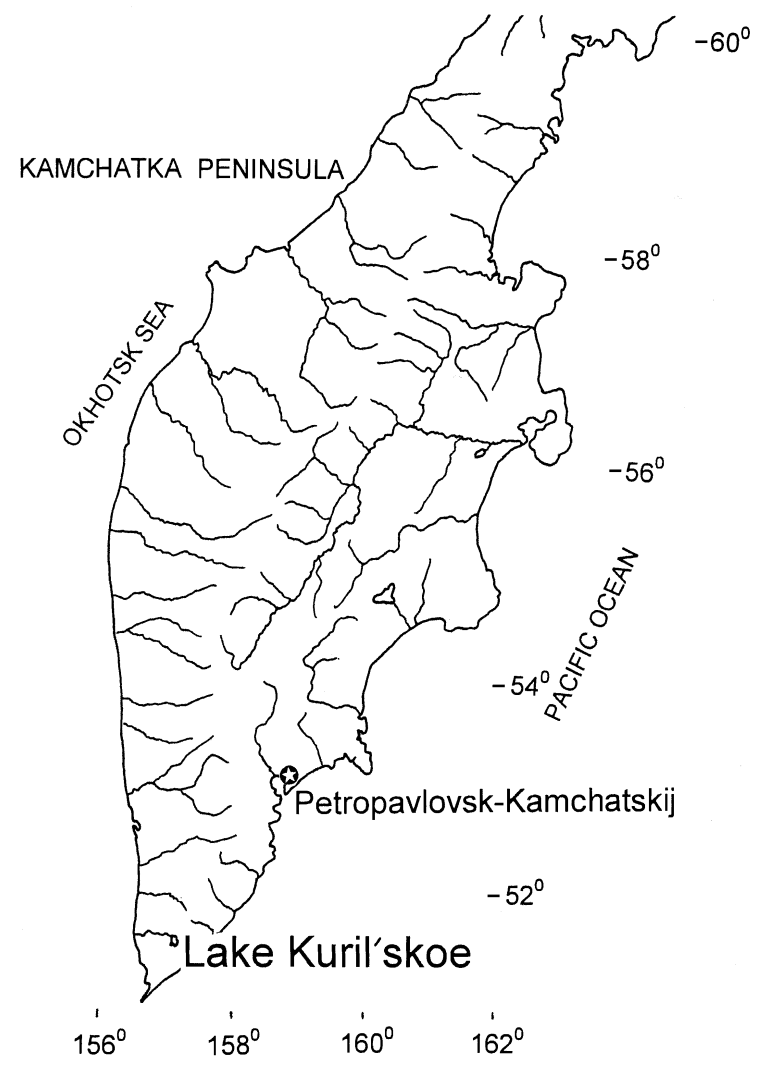

Fig. 1. Geographical location of Lake Kuril'skoe. 
mounts. Eleven specimens, mounted on a slide, were later deposited in the Royal Ontario Museum, Toronto, under \# ROMIZ 14742. No live material was available for study. Syntypes of Pachydrilus kamtschatkanus Michaelsen, 1929 (Zoological Museum of the Hamburg University, \# V 8088) were restudied as whole mounts in Canada balsam.

\section{RESULTS}

Lake Kuril'skoe is a large $\left(77 \mathrm{~km}^{2}\right), 313 \mathrm{~m}$ deep, oligotrophic, entirely freshwater lake. It lies $110 \mathrm{~m}$ above sea level, and is of volcanic origin. Enchytraeidae are common in the stony shallow-water zone, and relatively diverse, with at least 13 taxa (Timm 1999, Timm \& Vvedenskaja submitted).

Previously only the endemic Lumbricillus kamtschatkanus (= Pachydrilus kamtschatkanus Michaelsen, 1929) was recorded there dredged in large numbers from depths of 2-5 m in 1909. Michaelsen (1929) thought it was related to L. pagenstecheri. However, the ectal rosette of the spermathecae consisted of several small glands while the gland cover on the duct was replaced with a glandular epithelium. Subneural glands ("Kopulationsdrüsen") were less developed than described in L. pagenstecheri by Ude (1892) and (as L. georgiensis) Tynen (1969). Differences in the brain and nephridia were also noticed by Michaelsen (1929).

The restudied type series of $P$. kamtschatkanus consists of one clitellate (with ripe eggs) and four maturing or post-reproductive individuals, about $6 \mathrm{~mm}$ long and with 41-43 segments. They correspond to Michaelsen's description, including the thick-walled naked spermathecal duct in the clitellate specimen. No ectal rosette was observed. The ampulla was wider than the duct (respectively 55 and $30 \mu \mathrm{m}$ ) but with a similar thick wall and narrow lumen (Fig. 2). Thus, this species is neither identical nor closely related to L. pagenstecheri. Neither can it be confused with L. arenarius (Michaelsen, 1889), also known from this lake, which is characterized by three almost straight chaetae per bundle, and very large pear-shaped spermathecae with a naked ectal duct and a distinct glandular rosette on the ectal pore.

In the 1990s, L. pagenstecheri (=Lumbricillus sp. 1 sensu Timm 1999) dominated in the shallowest littoral of Lake Kuril'skoe whereas L. arenarius was less numerous and occurred deeper, at 4-13 m. L. kamtschatkanus was not observed. "Lumbricillus sp. 2" sensu Timm (1999) actually belongs to Mesenchytraeus (Timm \& Vvedenskaja submitted).

The characteristics of L. pagenstecheri from Lake Kuril'skoe are as follows (see also Fig. 3). Mature worms 8-12 mm long when preserved, with 41-51 segments. Chaetae almost straight, 4-5 (2-7) before clitellum, and slightly sigmoid, (2) 3-4 posteriorly, 58-110 $\mu \mathrm{m}$ long (longest on the mid-body) and 5-9 $\mu \mathrm{m}$ thick, without nodulus. Clitellum in XII-XIII, 40-50 $\mu \mathrm{m}$ thick, consisting of irregular small gland cells. Male pores with tubercle; penial bulb sometimes partially everted. Brain wider posteriorly; its posterior edge concave. Subneural glands in XIV-XV. Coelomocytes not seen in preserved material. Pharyngeal glands as three pairs, with dorsal and ventral lobes; dorsal connections in the two anterior pairs. 


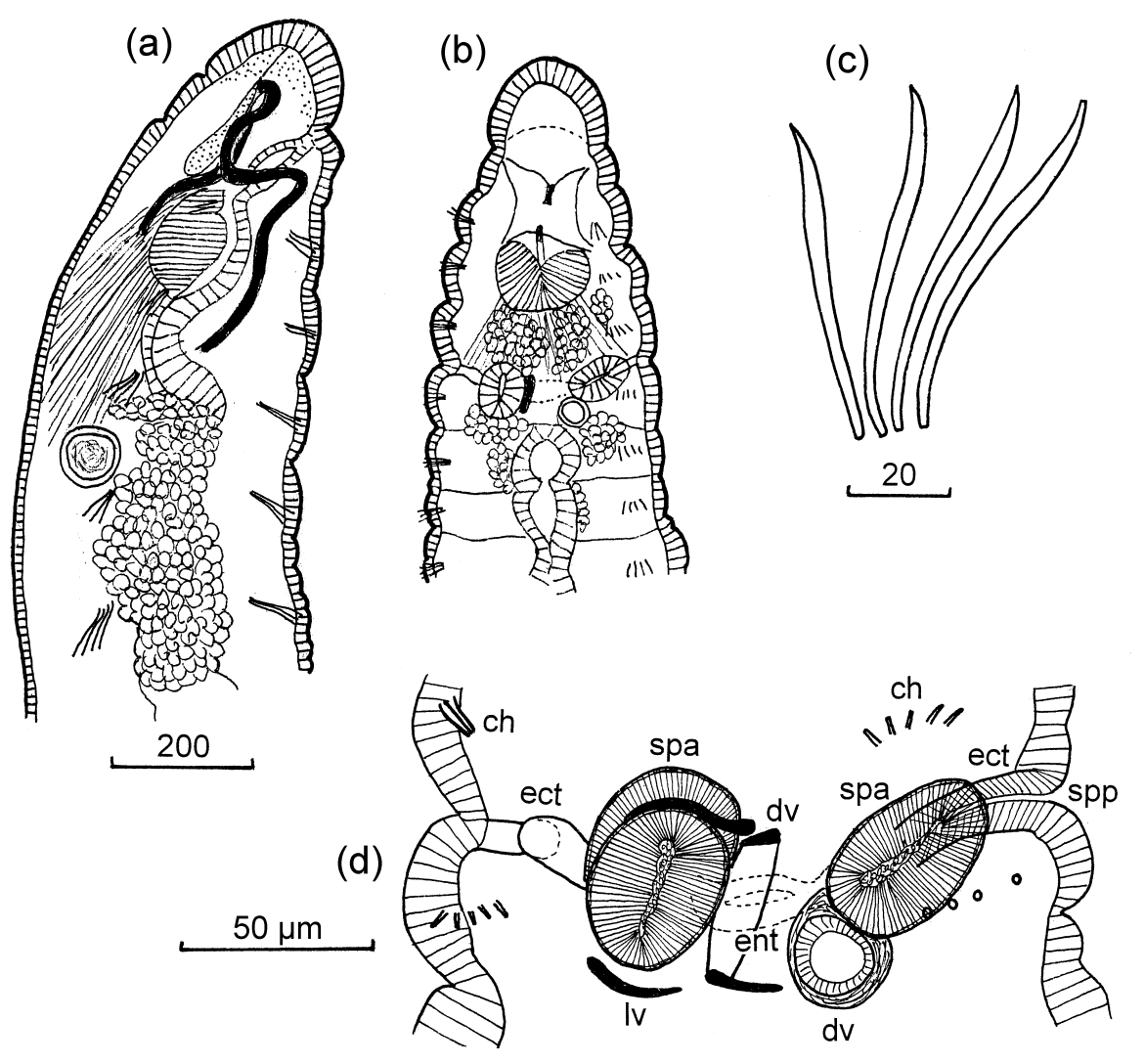

Fig. 2. Lumbricillus kamtschatkanus from Lake Kuril'skoe, syntypes. (a) - anterior end of a postreproductive specimen in side view; (b) - anterior end of a clitellate specimen from above; (c) - chaetal bundle; (d) - spermathecae of the clitellate specimen in situ. ch - dorsal chaetae of IV; $\mathrm{dv}$ - parts of the dorsal blood vessel; ect - ectal duct of spermatheca; ent - ental ducts of spermathecae; lv - lateral blood vessel; spa - spermathecal ampulla.

Chloragogenous tissue beginning in VI or VII. Intestine gradually dilating in VIII or IX. Dorsal vessel arising in XV or XVI but in some specimens traced from XII only. Postseptals of nephridia tadpole-like in side view, with an approximately $20 \mu \mathrm{m}$ long duct descending backwards in a bow from the roundish body.

Testes large and bush-like, filling IX-X, often stretching into VIII and XII. Male funnels $2-2.5$ times as long as wide $(230-350 \times 100-170 \mu \mathrm{m})$, bent, with $12-14 \mu \mathrm{m}$ wide lumen. Collar of the same width or slightly narrower $(63-140 \mu \mathrm{m})$. Vasa deferentia 11-16 $\mu \mathrm{m}$ wide, with lumen $5 \mu \mathrm{m}$, tightly coiled into paired ventral plates behind 11/12. Penial bulbs flat oval or partially bilobate (the smaller anterior/ lateral lobe can protrude from the male pore), 150-240 $\mu \mathrm{m}$ long, 135-210 $\mu \mathrm{m}$ high, and 115-290 $\mu \mathrm{m}$ wide. Their thin $(4 \mu \mathrm{m})$ muscular wall surrounds a mixture of muscular and glandular tissue; lumen $35 \mu \mathrm{m}$ wide. 

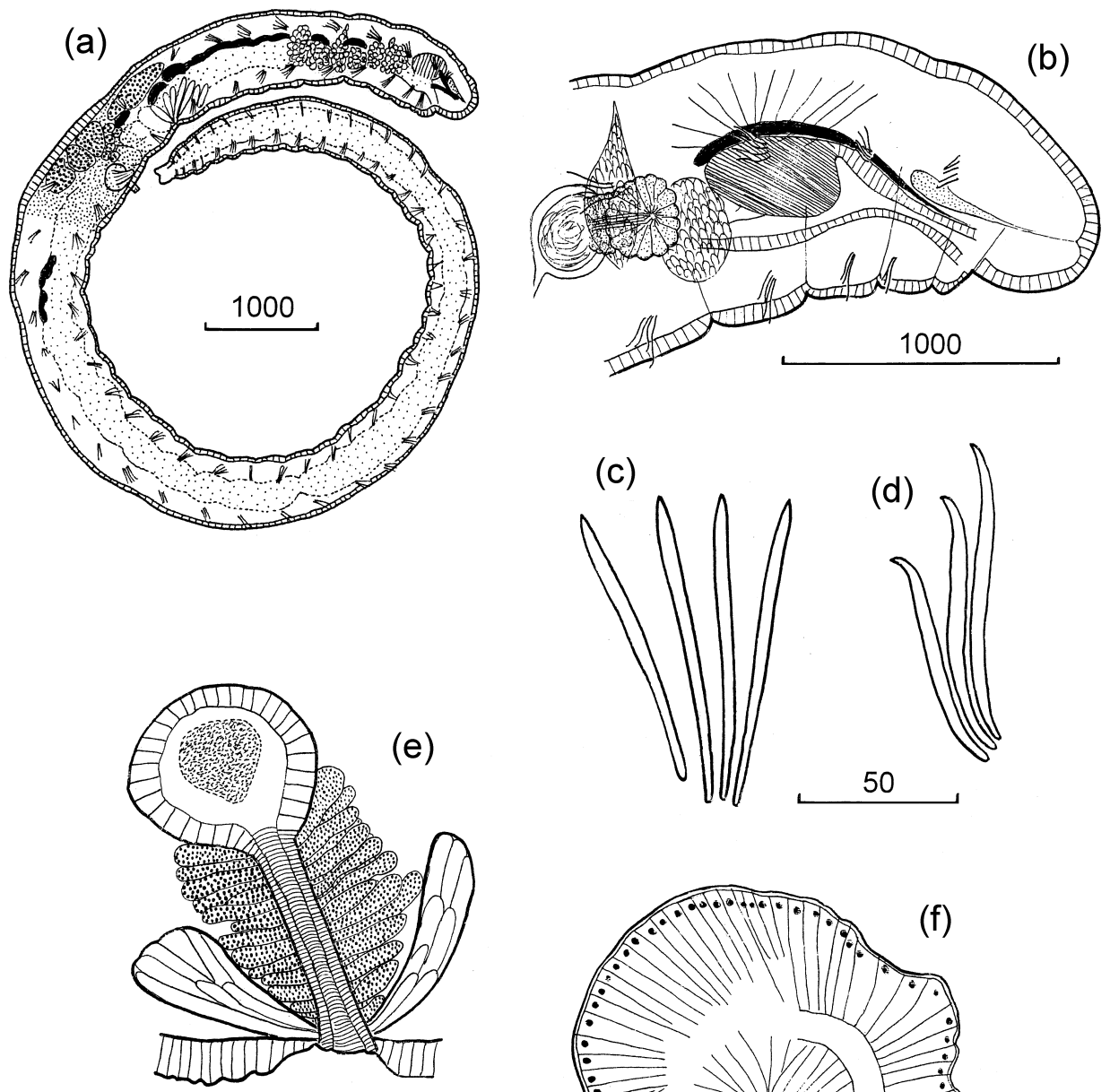

$100 \mu \mathrm{m}$

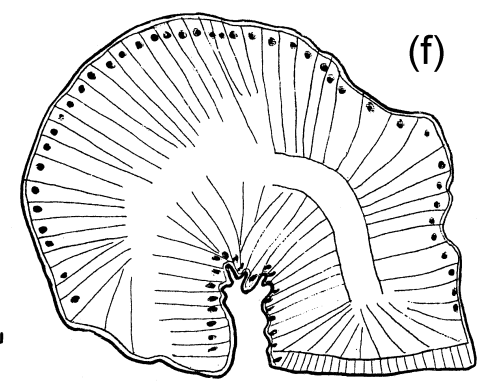

Fig. 3. Lumbricillus pagenstecheri from Lake Kuril'skoe. (a) - general view of a whole-mounted specimen; (b) - anterior end; (c) - anterior chaetal bundle from above; (d) - posterior chaetal bundle from side; (e) - spermatheca, reconstructed after sections; (f) - male funnel, from a section.

More than ten eggs in XII. Female funnels either as a thickened part of 12/13 (at least $50 \mu \mathrm{m}$ long, $24 \mu \mathrm{m}$ thick), or with two vertical, $60 \mu \mathrm{m}$ long lips. Egg ducts at $12 / 13,30 \mu \mathrm{m}$ long; female pores either in $12 / 13$ or slightly backwards.

Spermathecae in V with sphaerical, flattened, oval, or pear-shaped ampulla, $85-135 \mu \mathrm{m}$ wide in separate specimens; its wall smooth, 7-20 $\mu \mathrm{m}$ thick (sometimes thicker distally). Short $(80-115 \mu \mathrm{m})$ ental duct joining oesophagus in $\mathrm{V}$ or at the beginning of VI. Sperm in the ampulla coiled as one or several skeins. Ectal duct 
65-145 $\mu \mathrm{m}$ long and $27-30 \mu \mathrm{m}$ wide, sometimes medially dilated. Its wall consists of epithelial and muscular layers, and is covered with a $45-55 \mu \mathrm{m}$ thick mass of glands; its total width together with glands $112-125 \mu \mathrm{m}$. A rosette of higher glands, $110-200 \mu \mathrm{m}$ in diameter, surrounds the ectal end.

The above description is in good accordance with L. pagenstecheri as defined by Nielsen \& Christensen (1959) and Erséus (1976).

\section{DISCUSSION}

Other than L. pagenstecheri, the species of Lumbricillus with spermathecae of generally similar structure live in the marine littoral. Only L. pagenstecheri has been recorded, besides seashore, also from the inland habitats: polluted freshwater or rich moist soil in Europe (Ratzel 1869, Vejdovský 1879, Ude 1892), and a clean freshwater lake in Kamchatka (new data). The Kamchatkan population has, on average, a slightly shorter body $(8-12 \mathrm{~mm}$, against $14-18 \mathrm{~mm})$ and shorter sperm funnel (length/width ratio 2-3, against 3-4) than those reported by Nielsen \& Christensen (1959). There are also some minor differences at the beginning of the dorsal vessel, distribution of subneural glands etc. However, the differences are less than those in L. ritteri Eisen, 1904, and L. georgiensis Tynen, 1969, synonymized with L. pagenstecheri by Coates \& Ellis (1981) (see below). The main character of the species, the shape and structure of spermathecae, is persuasively identical with those depicted in Europe by Vejdovský (1879), Nielsen \& Christensen (1959), and Erséus (1976).

\section{North Atlantic species}

Only three valid Lumbricillus species with pagenstecheri-like spermathecae occur in the North Atlantic: L. pagenstecheri (with several synonyms, see below), L. semifuscus (Claparède, 1861), and L. algensis Erséus, 1977. L. henkingi (Ude, 1901) was synonymized with L. pagenstecheri by Nielsen \& Christensen (1959); and with L. aegialites Stephenson, 1922 and L. necrophagus Stephenson, 1922 by Stephenson (1925) and Nurminen (1965). Erséus $(1976,1977)$ and Coates \& Ellis (1981) hesitated to add L. kalatdlitus (Nurminen, 1970) from Greenland to the synonymy of L. pagenstecheri. However, it does not differ from the latter more than the other synonymous taxa; moreover, Nurminen (1970) did not record nominal L. pagenstecheri from the same material.

According to Erséus (1976), L. semifuscus differs from L. pagenstecheri in many aspects: thin glandular cover on the long ectal duct of spermatheca, small roundish ampulla, weakly divided testes confined to XI, sperm funnel only 1.5 times as long as wide, pharyngeal glands without dorsal connections but with the posterior ventral lobes extending into VII, almost straight chaetae, etc. Stephenson (1911) described it (as Marionina semifusca) as having strongly sigmoid chaetae, triangular testes, and a thin-walled spermathecal duct (glandular cover was depicted in the 
figure). In L. algensis, the spermathecal ampulla is very long, and the glandular cover is extending on its ectal portion. Erséus (1977) did not even compare this species with L. pagenstecheri.

\section{Northwestern Pacific species}

Thirteen Lumbricillus species with "pagenstecheri-spermathecae" (glandcovered ectal duct with an ectal rosette) have been recorded in the marine littoral and sublittoral of Russia and Japan by Yamaguchi (1937) and Shurova (1974, 1977, 1978, 1979, 1986): L. annulatus Eisen, 1904; L. nipponicus (Yamaguchi, 1937); L. mirabilis Tynen, 1969; L. kurilensis Shurova, 1974; L. orientalis Shurova, 1974; L. rufulus Shurova, 1974; L. corallinae Shurova, 1977; L. ignotus Shurova, 1977; L. pinquis Shurova, 1977; L. similis Shurova, 1977; L. lentus Shurova, 1978; L. taisiae Shurova, 1978; and L. sapitus Shurova, 1979. They differ from each other, as well as from L. pagenstecheri sensu Nielsen \& Christensen (1959), in having different combinations of various reproductive and somatic characters. Three species - L. corallinae, L. ignotus, and L. pinquis - are most distinct in having paired chaetae; probably they represent a separate clade. L. similis may be most closely related to L. pagenstecheri, differing only in being smaller $(7-8 \mathrm{~mm}$, with 38-45 segments) and with numerous (up to 13) posterior ventral chaetae. L. pagenstecheri itself has not been recorded in this region.

\section{Northeastern Pacific species}

At least nine valid species of Lumbricillus with spermathecae of pagenstecheri type were recorded from American side of the Northern Pacific by Eisen (1904), Tynen (1969), Coates (1981), and Coates \& Ellis (1981). These are L. pagenstecheri (Ratzel, 1869) (syn. L. ritteri Eisen, 1904, and L. georgiensis Tynen, 1969); L. merriami Eisen, 1904 (with var. elongatus Eisen, 1904); L. annulatus Eisen, 1904 (syn. L. vancouverensis Tynen, 1969); L. franciscanus Eisen, 1904 (with ssp. borealis Eisen, 1904 and unalaskae Eisen, 1904); L. mirabilis Tynen, 1969; L. qualicumensis Tynen, 1969; L. belli Tynen, 1969; L. tsimpseanis Coates, 1981; and L. curtus Coates, 1981.

Coates \& Ellis (1981) synonymized L. ritteri and L. georgiensis with L. pagenstecheri, thus considerably expanding the definition of the last. L. ritteri is large (up to $25 \mathrm{~mm}$ and 60-62 segments), and has very large, lobed subneural glands in XIII-XVII. L. georgiensis is 15-20 mm long, with 49-58 segments, and subneural glands in XV-XIX. Its sperm in the spermathecal ampulla was said to be disposed in pyriform packets as in some Northwestern Pacific species described by Shurova $(1977,1978)$ but not in L. similis, which is otherwise close to L. pagenstecheri. However, Coates \& Ellis (1981) did not find these packets even in syntypes of $L$. georgiensis. Sperm funnels are similar in L. pagenstecheri, L. ritteri, and L. georgiensis. 
The synonymies proposed by Coates \& Ellis (1981) as well as their new specimens extended the geographic range of L. pagenstecheri to the Northeastern Pacific, which thus became a circumholarctic species. The nominal L. pagenstecheri has not been recorded from the Russian side of the North Pacific except from a freshwater lake (Kuril'skoe). This lacustrine population is clearly closer to the conspecific European populations than to L. similis, its closest known relative in the Northwestern Pacific.

The total number of valid nominal species in L. pagenstecheri group from the North Pacific reaches 20. Only two species (L. annulatus and L. mirabilis) are without any doubt known from both sides of the Pacific. A potential identity of the Northeastern L. qualicumensis with L. ignotus from the Russian side, and L. merriami with L.annulatus or/and L.nipponicus was discussed by Coates \& Ellis (1981). A clinal infraspecific variability between neighbouring populations (which can be treated as subspecies) is plausible. Thus the taxonomic rank of separate nominal species or subspecies with a limited distribution range can be conditional, particularly in comparison with the Holarctic, variable L. pagenstecheri.

Based on the spermathecal form, three series of the Lumbricillus species of this group occur along the Pacific.

1. Small ampulla not considerably wider than the ectal duct. The latter is relatively long, with covering gland cells gradually decreasing in length from the ectal rosette towards the ampulla. L. annulatus, L. merriami, and L. nipponicus.

2. Large roundish or pear-shaped ampulla, distinct medium or short ectal duct with dense glandular cover, and a large compact glandular crown near the ectal pore. 15 species, including $L$. pagenstecheri with its possible synonyms.

3. Proportions of ampulla and duct as in the latter group; glands present but poorly developed both on the duct and at the spermathecal pore. L. tsimpseanis and L. lentus. These species form a transition to the freshwater L. kamtschatkanus and several other Lumbricillus with bare ectal spermathecal duct.

\section{CONCLUSIONS}

There is a large cluster (more than 20) of Lumbricillus species sharing with L. pagenstecheri a distinct glandular cover on the ectal spermathecal duct, and a rosette at its ectal end. Their largest diversity is concentrated on the coasts of the North Pacific. Terrestrial (wet soil) and freshwater populations are known only for L. pagenstecheri itself, in Europe and in the Far Eastern Lake Kuril'skoe. L. pagenstecheri is also the most variable and the only circumholarctic species in the group.

Is Lumbricillus pagenstecheri sensu Nielsen \& Christensen (1959) and Coates \& Ellis (1981) the most euryhaline and most easily dispersing member of a large cluster of related species? Or is the currently recognized species an assemblage (superspecies) of different, local species, most of them Pacific? A wide distribution 
of L. pagenstecheri in the North Atlantic and Northeast Pacific (accepting the presence of a large number of other, related species in the Pacific) is in accordance with the first hypothesis. The second hypothesis may be corroborated by the large variability of $L$. pagenstecheri, as well as by lack of its formal records on the Asian side of the Pacific. However, it may just be undiscovered there, or represented under a different name (e.g., L. similis). The actual taxonomic status of many slightly different local forms (e.g., L. ritteri) remains obscure.

Presence of L. pagenstecheri in Lake Kuril'skoe may mean that it does occur in the marine littoral of the Northwestern Pacific. Maybe this lake was a brackishwater lagoon, becoming fresh after a tectonic rise. Freshwater populations of other seashore enchytraeids occur in this lake - L. arenarius, Marionina klaskisharum Coates, 1983, and M. charlottensis Coates, 1980, according to Timm \& Vvedenskaja (submitted).

The diversity of the L. pagenstecheri group is much less in the Atlantic than in the Pacific, maybe due to a shorter geological history of the former. Future molecular studies may shed light on the actual relations between these species and infraspecific taxa.

\section{ACKNOWLEDGEMENTS}

I am greatly indebted to Dr. T. L. Vvedenskaja (Kamchatkan Branch of the Pacific Institute of Fisheries and Oceanography) for the material from Lake Kuril'skoe; to Dr. H. Ruhberg (Zoologisches Museum of Hamburg University) for the loan of the type series of Lumbricillus kamtschatkanus; and to Dr. K. A. Coates (Bermuda Biological Station) for her valuable criticism on the manuscript. The study was supported by the core grant $0362482 \mathrm{~s} 03$ "Formation and changes of the biological diversity under the human impact in different lake types (EstoniaDenmark-Netherlands)".

\section{REFERENCES}

Coates, C. 1981. New species of Lumbricillus (Oligochaeta, Enchytraeidae) from littoral habitats of British Columbia. Can. J. Zool., 59, 1302-1311.

Coates, C. \& Ellis, D. V. 1981. Taxonomy and distribution of marine Enchytraeidae (Oligochaeta) in British Columbia. Can. J. Zool., 59, 2129-2150.

Eisen, G. 1904. Enchytraeidae of the west coast of North America. Harriman Alaska Ser., 12.

Erséus, C. 1976. Littoral Oligochaeta (Annelida) from Eyafjörður, north coast of Iceland. Zool. Scr., 5, 5-11.

Erséus, C. 1977. Marine Oligochaeta from the Koster area, west coast of Sweden, with descriptions of two new enchytraeid species. Zool. Scr., 6, 293-298.

Michaelsen, W. 1929. Oligochäten der Kamtschatka-Expedition 1908-1909. Ann. Mus. Zool. Acad. Sci. URSS, 30(2), 315-329.

Nielsen, C. O. \& Christensen, B. 1959. The Enchytraeidae critical revision and taxonomy of European species. Nat. Jutl., 8-9.

Nurminen, M. 1965. Enchytraeid and Lumbricid records (Oligochaeta) from Spitsbergen. Ann. Zool. Fenn., 2, 1-17. 
Nurminen, M., 1970. Records of Enchytraeidae (Oligochaeta) from the west coast of Greenland. Ann. Zool. Fenn., 7, 199-209.

Ratzel, F. 1869. Beiträge zur anatomischen und systematischen Kenntniss der Oligochaeten. Z. Wiss. Zool., 18(4), 563-591.

Reynolds, J. W. \& Cook, D. G. 1976. Nomenclatura Oligochaetologica. The University of New Brunswick, Fredericton.

Shurova, N. M. 1974. Enchytraeidae of the genus Lumbricillus (Oligochaeta) from the intertidal zone of the Kurile Islands. Acad. Sci. USSR, Far Eastern Centre, Inst. Mar. Biol., Arch., 1, $128-136$.

Shurova, N. M. 1977. New littoral species of the genus Lumbricillus (Oligochaeta). Mar. Biol. (Vladivostok), 1, 57-62.

Shurova, N. M. 1978. The intertidal oligochaets from the eastern coast of Kamchatka. In Intertidal Zone of the Bering Sea and Southeastern Kamchatka, pp. 98-106. Academy of Sciences of the USSR, Far Eastern Centre, Institute of Marine Biology, Moskva.

Shurova, N. M. 1979. Enchytraeids (Oligochaeta) of the Far Eastern Seas of the USSR. Acad. Sci. USSR, Far Eastern Centre, Inst. Mar. Biol., Arch., 15, 75-90.

Shurova, N. M. 1986. Some pecularities of sexual reproduction in littoral enchytraeids (Oligochaeta, Enchytraeidae) of the Vostok Bay in the Sea of Japan. Zool. Zh., 65(5), 726-731.

Stephenson, J. 1911. On some littoral Oligochaeta of the Clyde. Trans. R. Soc. Edinb., 48(1913), $31-65$.

Stephenson, J. 1925. The Oligochaeta of Spitzbergen and Bear Island: some additions and summary. Proc. Zool. Soc. Lond., 1925, part III, 1293-1322.

Timm, T. 1999. Lake Kuril'skoe as an enchytraeid site: preliminary data. Newsl. Enchytraeidae, 6, $11-14$.

Timm, T. \& Vvedenskaja, T. L. Submitted. Oligochaeta of Lake Kuril'skoe (Russian Far East). Species Diversity.

Tynen, M. J. 1969. New Enchytraeidae (Oligochaeta) from the east coast of Vancouver Island. Can. J. Zool., 47, 387-393.

Ude, H. 1892. Würmer der Provinz Hannover. I. Jahresber. Naturhist. Ges. Hannover, 40-41, 63-98.

Vejdovský, F. 1879. Beiträge zur vergleichenden Morphologie der Anneliden. I. Monographie der Enchytraeiden. Friedrich Tempský, Prag.

Yamaguchi, H. 1937. The fauna of Akkeshi Bay. III. Oligochaeta. J. Fac. Sci. Hokkaido Univ., Ser. VI, Zool., 5(3), 137-142.

\section{Liigi Lumbricillus pagenstecheri (Oligochaeta, Enchytraeidae) levikust ja taksonoomilisest piiritlemisest}

\section{Tarmo Timm}

Lumbricillus pagenstecheri (Ratzel, 1869) on levinuim ja eurühaliinseim selle perekonna peamiselt mere litoraalis elavate liikide rühmast, keda iseloomustab näärmekiht seemnehoidla välimisel juhal ja seemnehoidla ava ümbritsev näärmepärg. Ainsa selle rühma liigina on teda leitud ühtaegu nii Atlandi kui Vaikse ookeani randadelt, samuti mullast. Kurilskoje järves Kaug-Idas leiti selle liigi merest isoleeritud mageveeline populatsioon, mis pole identne samast järvest varem teada oleva liigiga L. kamtschatkanus Michaelsen (1929). 